\title{
MAGYAR NÉPKUTATÁS A 20. SZÁZADBAN
}

Paládi Kovács Attila Magyar népkutatás a 20. században címü kötete az MTA Bölcsészettudományi Kutatóközpont Néprajztudományi Intézete és a L'Harmattan Könyvkiadó közös, Documentatio Ethnographica sorozatában jelent meg 2018-ban.

A mü, amely a Magyar Népismeret a 19. században. Elöfutárokés klasszikusok címü 2016-ban megjelent kötetének folytatása, a 20. századi magyar etnográfia és folklorisztika tizennyolc kutatójának munkásságát mutatja be. A kötetet záró huszonhét kép kép ezen tudósok és néhány kortársuk fényképeinek segítségével hozza az olvasóhoz közelebb Bátky Zsigmond, Viski Károly, Győrffy István, Braun Soma, Ortutay Gyula, Vargyas Lajos, Gunda Béla, Manga János, Keszi Kovács László, Keszi Kovács Péter, Bakó Ferenc, Belényesy Márta, K. Csilléry Klára, Hoffmann Tamás, Szabadfalvi József, Füzes Endre, Tárkány Szücs Ernő, Hofer Tamás egyéniségét.

Személyiségük, pályaképük felvázolása, tudós alkatuk alakulásának és népkutatói törekvéseiket motiváló céljaik és ambícióik hátterének bemutatását összegzi a szerző, a korábban már máshol megjelent közlések kötetté füzésével.

Bátky Zsigmond, az alapos terepmunkás 1920-1934 között igazgatta a Néprajzi Múzeumot, és életében ő volt a magyar népkutatás legolvasottabb, az európai és a magyar etnográfiai problematika leginkább tájékozott tudósa.

A népművészeti irányultságú Viski Károly a kolozsvári, majd a pesti egyetemen, Győrffy István, az állattartás kutatója 1934-1939 között a budapesti egyetemen nevelt kiváló tanítványokat az MTA tagjaként.

Braun Somát a népmeséről és a primitív kultúráról írott kötetei teszik érdemessé a kötetbe kerülésre.

Ortutay Gyula a személyiséget előtérbe hozó magyar népköltésgyüjtést, -elemzést és -közreadást szorgalmazva teremtette meg a magyar folklorisztikát, és vált a népkutatás meghatározó alakjává.

Vargyas Lajos, a klasszikus magyar népballadakincs rendszerezője és európai kapcsolatainak feltárója, valamint a magyar népzene korai rétegeinek kutatója volt.

Gunda Béla, a tárgyi néprajz terepkutató iskolateremtő professzora volt a kolozsvári és a debreceni egyetemen és a továbbélő kulturális archaikus elemek vizsgálatát foglalta publikációkba.

Manga János az északi magyar pásztorművészet, a népszokások, a népdalok, a hangszerkultúra és a palóc népcsoport kutatásában alkotott maradandót.

Keszi Kovács László, a néprajzi „gyalogfilmes”, az anyagi és szellemi kultúra számos elemét megörökítő fénykép- és filmfelvételei és kutatásai felfedezés 
értéküek, akárcsak az erdélyi juhászatot és a hostátiak temetkezését bemutató tanulmánya.

Keszi Kovács Péter a Néprajzi Múzeum Adattárának kialakításával és a néprajzi dokumentáció kiépítésével szolgálta a tudományosságot, és számos közöletlen írása is archív kutatási forrássá vált.

Bakó Ferenc palóckutatásai, településforma elemzései és a két évtizeden át folytatott kollektív terepmunka vizsgálatai jelentősek.

Belényesy Márta a középkor anyagi kultúráját és az agrárium állapotát tárta fel levéltári források segítségével a történeti néprajzi „sui generis” módszerével, technikák és innovációk kutatásával.

K. Csilléry Klára a magyar népi lakáskultúra és bútorzat, valamint a tárgyalkotó népmüvészet tárgycsoportjait vizsgálta a stílusirányok szem előtt tartásával, a müvészet, a szótörténet és a régészet eredményeinek felhasználásával.

Hoffmann Tamás az agrártörténet-írás meghatározó alakja volt, a Néprajzi Múzeum igazgatójaként innovatív kiállításokat hozott létre.

Szabadfalvi József megyei múzeumigazgatóként, a pásztorkodás kutatásával jeles monográfiákkal gyarapította az anyagi müveltségről szóló ismereteinket.

Füzes Endre a szentendrei Szabadtéri Néprajzi Múzeum, a magyar Skanzen igazgatójaként a településtörténet, a népi építészet és a gabonatárolás kutatásával gazdagította népéleti tudásunkat.

Tárkány Szücs Ernő a hagyományos társadalom müködésmódját kutatta, és a magyar jogi népszokások feltárását végezte el számos munkájában.

Hofer Tamás Fél Edittel együtt nemzetközi ismertségre tett szert a lokális falusi társadalom Átányban végzett, mélyfúrás jellegü, világon egyedülálló kutatásával. Az európai néprajz és az angolszász kulturális antropológia közelítésén és oktatásán fáradozott, és a történeti antropológia hazai meghonosítója volt.

Paládi Kovács Attila Magyar népkutatás a 20. században címü kötetének befejező hatvan oldalán a szerző a néprajz szak és intézményeinek helyzetváltozásait és feladatvállalásait ismertető írásai szerepelnek: a néprajz mint akadémiai diszciplína Magyarországon, a 125 éves Ethnográfia köszöntése, a Magyar Néprajzi Atlasz kérdőíve, gyüjtési munkálatai és adatbázisa, a Magyar Néprajz kézikönyv, nemzetiségi néprajzi kutatások, a magyar néprajztudomány 20. századi helyzete, kutatásai és perspektívái, helyzetértékelés és személyes változások.

A magyar népkutatás 20. században tevékenykedő bemutatott tudósainak munkássága nemcsak beépült a magyar néprajz ismerettárába és a felsőoktatásba, de méltán számíthat a társtudományok és a tudományos ismertterjesztés érdeklödésére is.

A tudományág magyar kutatóinak legjobbjai lépést tartanak a friss nemzetközi trendekkel és kezdeményező szerepet játszanak az etnicitás, a népi és nemzeti kultúra kapcsolata, a neofolklorizmus, a szubkultúrák vizsgálata, a vizuális do- 
kumentálás: fotográfia, dokumentumfilm-készítés, digitális néprajz, antropológiai terepmunka és archiválás területein.

Az etnikai folyamatok, a migráció, a vallási konfliktusok, a határokon túlra kiterjedő nemzetállamok kultúrája és a kultúra etnikus jegyei, valamint az egységes Európai Egyesült Államok gondolata, a világfalu - „global village” - elmélethez és a tömegkultúra vizsgálatához kapcsolódó identitásproblémák fontos alkalmazott néprajzi, antropológiai és szociológiai kutatásoknak jelölnek ki feladatokat.

Jelenkorunk néprajzkutatóinak, kulturális antropológusainak munkássága, a müködő kutató intézmények és múzeumok, valamint paradigmaváltásaik is megérdemlik majd az értő szakmai összegzést és tudománytörténeti bemutatást a jövő generációk számára.

Paládi Kovács Attila: Magyar népkutatás a 20. században. (Documentatio Ethnographica 32.) Budapest: MTA BTK Néprajztudományi Intézete - L'Harmattan Könyvkiadó. http://real.mtak.hu/90835/1/Magyar\%20n\%C3\%A9pkutat\%C3\%Als beliv_press.pdf

Tari János Mihály

ethnográfus-szociológus, egyetemi docens, rendező-operatőr, stúdióvezető Károli Gáspár Református Egyetem Bölcsészet- és Társadalomtudományi Kar Társadalom- és Kommunikációtudományi Intézet 